\title{
The Journey to Authenticity: An Analysis of Undergraduate Personal Development
}

\author{
Meagan Scott \\ Graduate Teaching Associate \\ Oklahoma State University \\ 445 Agricultural Hall \\ Stillwater, OK 74078 \\ meagan.scott@okstate.edu \\ Ashley S. Whiddon \\ Agricultural Education Teacher \\ Peach County High School \\ 900 Campus Drive \\ Fort Valley, GA 31030 \\ ashley.whiddon@okstate.edu \\ Dr. Nicholas R. Brown \\ Assistant Principal \\ Jenks Public Schools \\ Jenks Middle School \\ 205 East B Street \\ Jenks, OK 74037 \\ nick.brown@jenksps.org \\ Dr. Penny P. Weeks \\ Professor \\ Oklahoma State University \\ 442 Agricultural Hall \\ Stillwater, OK 74078 \\ penny.weeks@okstate.edu
}

\begin{abstract}
This instrumental case study sought to determine how collegiate-level students changed throughout a personal leadership development course. Document analysis of an archived course assignment was employed to analyze the students' perceptions of their personal leadership development. Four themes emerged from the analysis: (a) self-evolution, (b) cognitive gain, (c) perceived self-awareness, and (d) framework confusion.
\end{abstract}




\section{Introduction}

The authentic leadership process begins with developing authenticity, or being true to the self, and is accomplished through self-awareness, self-acceptance, and authentic actions and relationships (Gardner, Avolio, Luthans, May, \& Walumbwa, 2005). Authentic leadership is a root construct, meaning it underlies the basis for what constitutes other forms of positive leadership (Avolio \& Gardner, 2005). When a leader's actions are genuine and focused on the development of the self and others, the effectiveness of participative, achievement-oriented, transactional, supportive, and other forms of leadership are likely enhanced (Avolio \& Gardner, 2005). Authentic leadership requires heightened levels of self-awareness, leading to authentic leaders knowing where they stand on important issues, values, and beliefs (Avolio \& Gardner, 2005; Lloyd-Walker \& Walker, 2011). In fact, Gardner et al. proposed, "authentic leaders are more aware of, and committed to, their core end values" (2005, p. 350). Leading students to develop as authentic leaders goes beyond the traditional classroom lecture format.

Teaching leadership at the collegiate level is challenging in that teachers find themselves explaining abstract concepts and theories to students (Halpern, 2000; Williams \& McClure, 2010), thus making exploring new, innovative ways of teaching leadership important for classroom delivery (Williams \& McClure, 2010). Research has been conducted to examine various teaching methods as it pertains to leadership (Williams \& McClure, 2010; Williams, Townsend, \& Linder, 2005; Wimmer, Meyers, Porter, \& Shaw, 2012) and has shown that students retain more leadership concepts when teachers utilize methods where education occurs informally, incidentally, and experientially, as opposed to employing the traditional lecture format (Williams \& McClure, 2010). Additionally, Williams et al. (2005) found that students retained their leadership knowledge after taking leadership courses one, two, and three years later.

Today's traditional-aged college students are not like previous generations. Known as Millennials, these individuals are technologically savvy (Kaiser Family Foundation, 2005), and welcome variability in the classroom including teamwork, experiential learning activities, structure, entertainment, and technology (Raines, 2002). Effective teachers incorporate enthusiasm and variability in their classrooms (Rosenshine \& Furst, 1973), and comprehension and application of leadership concepts can be enhanced when combining these characteristics (Wimmer et al., 2012). Helping students become self-aware and explore their values and vision necessitates an open, reflective, and creative learning environment, and can lead to the acquisition of leadership skills (Pennington, 2006). Although authentic leadership development is a lifelong process, it can be enhanced through a formal collegiate-level course where leadership concepts are taught through interactive activities, self-reflection assignments, and class discussions (Pennington, 2006).

Authentic leadership development should be a significant component of a collegiate-level leadership program (Pennington, 2006); therefore Oklahoma State University offers a course that provides personal leadership development as an essential building block toward authenticity. The National Leadership Education Research Agenda (NLERA) identified Teaching, Learning, and Curriculum Development as a research priority area with the following outcome: "Explore curriculum development frameworks to enhance the leadership education transfer of learning" 
(Andenoro et al., 2013, p. 1). Hence, we analyzed an archived class assignment that was conceptually grounded in a relatively new curriculum framework in a personal leadership development course offered at Oklahoma State University. Specifically, we employed the instrumental case study approach (Stake, 2005) to determine how students' Discovering Leadership Framework (DLF) changed throughout the duration of the course.

\section{Description of the Case: A Fictional Vignette for Understanding}

Holley entered the classroom on the first day of her personal leadership development class assuming it would be the typical, mundane college class routine with lectures, presentations, and note taking; however, she quickly learned that the class would not be your ordinary college class. In just the second class-meeting, she found herself bidding for the most important leadership traits in a trait auction. During week two, she was working in a small group with students she had just met to prepare a presentation for the class about generational diversity in the workplace. During the next couple of weeks, she was trekking across campus in search of leaders to interview. Holley thought to herself, "What next?" as she never knew what activity to expect. The class never did disappoint, as Holley was excited the day her class was charged with the task of debating against each other about their philosophy regarding strengths. One day while glancing around the classroom, Holley realized that she was surrounded by a variety of students, representing numerous majors and interests. She had assumed the class would be the typical agricultural leadership cohort that was in all of her other classes, but was pleasantly surprised to meet students from across different disciplines. They all shared one common purpose, the desire to take a course on personal leadership development. As the semester came to a close, Holley told some of her friends that she learned a great deal about herself during the course without even realizing it. When asked to describe her personal leadership development class, Holley quickly responded, "It's interactive, it's hands-on, and I now know my values, my vision, my strengths, and who I am as a leader."

\section{Conceptual Framework}

The personal leadership development course was centered on guiding the students toward personal authenticity. This was achieved by helping the students determine their personal values, leadership vision, top strengths, and motivations to lead. Discovering the Leader in You (King, Altman, \& Lee, 2011) served as the course textbook for the journey. Through a systematic approach, the text helps students understand explicitly how leadership fits into their lives, what unique leadership qualities they possess, and the impact the students want to have on the world as a leader (King et al., 2011). Students embark on a personal development journey to identify drift within their lives and how to move beyond drift to leadership clarity (King et al., 2011). King et al. (2011) described drift as having doubts about one's capabilities, questioning how to leverage one's talents, or being "simply confused about the leader within" (p. 4). Clarity, on the other hand, varies depending on the perceptions of those involved, but can best be explained as being certain "about [one's] goals as a leader" (p. 4). To promote this movement from drift to clarity, King et al. (2011) created the Discovering Leadership Framework (DLF). The DLF provides a visual interpretation of how an individual's leadership vision, values, skills, and motivation align with organizational and personal realities (King et al., 2011). The DLF is based on five key topics: current organizational realities, leadership vision, leadership values, 
leadership profile, and current personal realities (King et al., 2011) (Figure 1). These topics serve as the core foundation of the personal leadership development course and, therefore, guided our data analysis efforts.

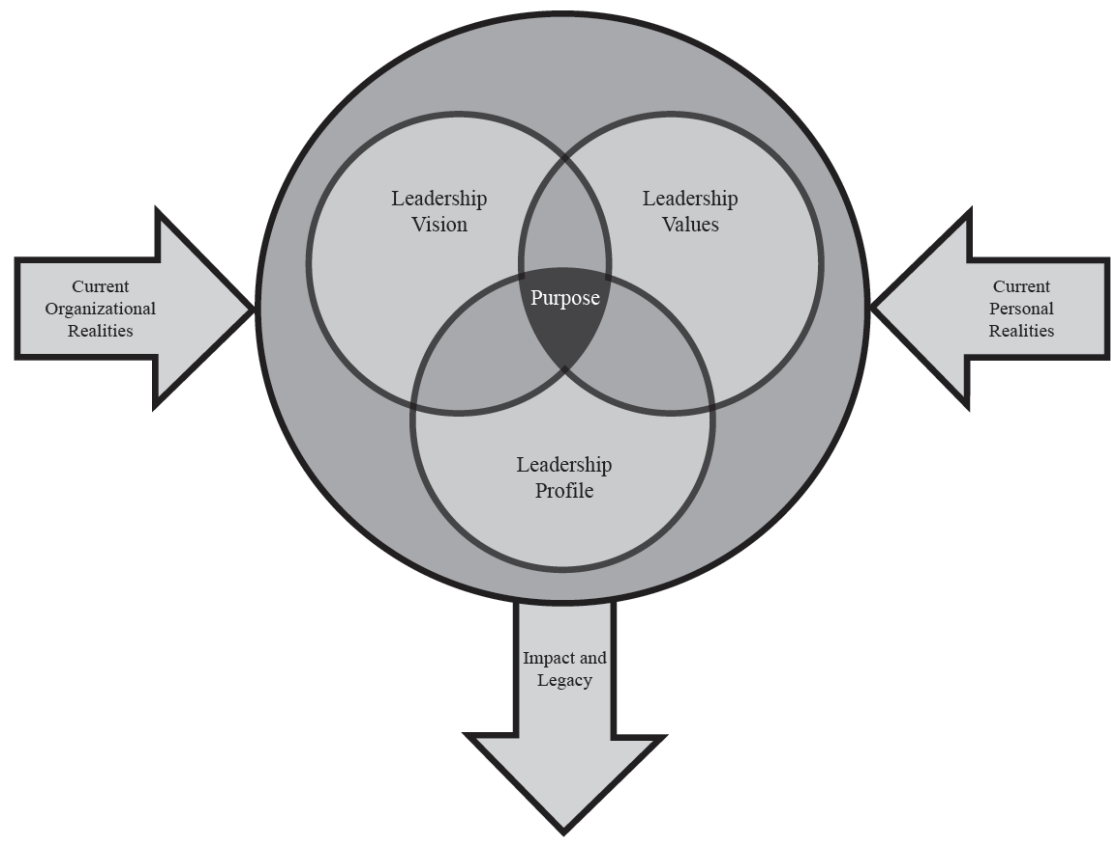

Figure 1: Discovering Leadership Framework. Adapted from Discovering the Leader in You (p. 153), by S. N. King, D. G. Altman, \& R. J. Lee, 2011, San Francisco, CA: Jossey-Bass. Copyright 2011 by John Wiley \& Sons, Inc. Adapted with permission.

\section{Focus of the Case through Issues Identification}

Literature aided in identifying two important issues that guided the case study. Our professional experiences coupled with literature brought forth these etic issues (Stake, 1995). Issue 1: Are undergraduate students in a personal leadership development course advancing from drift to clarity? Issue 2: Are students progressing through the emotional intelligence phases to achieve self-awareness?

\section{Development of Issues}

As the world today is rapidly changing with technological developments, economic challenges, and the expected access to leaders 24/7, many leaders are left with little or no energy to bring their best leadership to the table. The first issue is a result of these concerns. Because of these apprehensions, many leaders have started to question their abilities, the direction of their lives, and their hope for their future (King et al., 2011). Known as drift, leaders tend to go through the motions without advancing to their optimal leadership level. All leaders experience drift at some point, but problems arise when leaders stay adrift for an extended period of time. Rather than consciously choosing to make decisions, leaders simply make choices by default 
(King et al., 2011). Employing the DLF encourages students in a personal leadership development course to systematically assess their current leadership and life situations and move from drift to clarity, a point where they can better see the role of leadership in their lives (King et al., 2011). Clarity is the desired destination of students enrolled in the personal leadership development course at Oklahoma State University.

Developing one's authenticity through "self-awareness, self-acceptance, and authentic actions and relationships" (Gardner et al., 2005, p. 345) serves as a path to self-clarity. However, those low in self-clarity typically emulate immature defense styles and fail to acknowledge and settle negative emotions (Campbell et al., 1996; Ungerer, Waters, Barnett, \& Dolby, 1997; Vaillant, 1992). College students reach maturity as they move through the vectors of identity development (Chickering, 1969; Chickering \& Reisser, 1993). Authentic leaders demonstrate self-clarity, as their values, identity, emotions, motives, and goals are in alignment (Gardner et al., 2005). Since the clarity and certainty of self-knowledge are important determinants of psychological well-being (Kernis, 2003), authentic leaders are expected to convey increased levels of self-clarity and self-certainty (Gardner et al., 2005). The literature pivots on a definitive issue - are leaders progressing through drift to reach clarity?

The second issue arises as a result of student emotional intelligence progression during the personal leadership development course. Emotional intelligence "is a type of social intelligence that involves the ability to monitor one's own and others' emotions, to discriminate among them, and to use the information to guide one's thinking and actions" (Mayer \& Salovey, 1993, p. 433). Most effective leaders have a high degree of emotional intelligence (Goleman, 1998). Those lacking emotional intelligence can have excellent training, insightful minds, and brilliant ideas, but still will not make great leaders (Goleman, 1998). Self-awareness, "having a deep understanding of one's emotions, strengths, weaknesses, needs, and drives, "is the first component of emotional intelligence (Goleman, 1998, pp. 95-96). Those who are self-aware understand their values and goals and make decisions that are congruent with both. They are also more confident about their abilities and will honestly admit times of failure (Goleman, 1998). Although people are born with a certain amount of emotional intelligence, it can be learned and increases with age (Goleman, 1998). However, leaders more commonly refer to this phenomenon as maturity. Although emotional intelligence naturally increases with age, training is still needed. Desire and a conscious effort must accompany training in order to acquire high emotional intelligence (Goleman, 1998).

Cherniss and Goleman (1998) defined four phases of emotional intelligence development among students. These phases include preparation, training, transfer and maintenance, and evaluating change. The preparation phase involves assessing personal strengths and limitations, giving careful feedback, increasing learner choice, encouraging input, connecting goals and values, modifying expectations, and determining readiness. However, students must commit to a change that will take place over a period of time even before the training can begin. College students already have perceptions of themselves and their relations with others, making social and emotional learning a challenge (Cherniss \& Goleman, 1998). Individuals are also typically less aware of their social and emotional weaknesses than technical deficiencies (Cherniss \& Goleman, 1998; Weisinger, 1998). Students move through four stages of readiness for change (Prochaska, Norcross, \& DiClemente, 1994), including: (a) deny need for change; (b) aware of 
the need to improve but unsure if anything can be done or delay action; (c) recognize the problem and understand there are alternatives, but have no plan; and (d) have a plan but not yet put into action (Cherniss \& Goleman, 1998).

In the second phase of emotional intelligence development, training phase, it is very important for the student and instructor to have a positive relationship. Experiential activities, as opposed to lectures and readings, performed in small groups can help to improve self-awareness (Cherniss \& Goleman, 1998). The next phase of emotional intelligence development includes transfer and maintenance. Success in the transfer and maintenance phase largely depends on faculty and administrative support (Cherniss \& Goleman, 1998). A supportive environment promotes the continued use of social and emotional skills. Continuous reflection is extremely important since self-awareness is a basis for social and emotional competence. Evaluating change promotes continuous emotional intelligence improvement (Cherniss \& Goleman, 1998). Assessment of students' emotional intelligence provides an understanding of their current level and can stimulate growth. The process is clear but raises the question - are students progressing through the emotional intelligence phases to achieve self-awareness?

\section{Emerging Theoretical Lens}

A theory emerges based on the reported data in qualitative research (Stake, 1995). Through analysis and triangulation of the archived class assignment in an undergraduate personal leadership development course, Chickering's (1969) theory of identity development emerged. The theory was influential in framing how traditional-aged college students develop psychosocially. Chickering (1969) recognized that students in higher education face unique challenges and opportunities, and that these students experience changes in more areas than just intellectual development. To address this, he identified seven general changes that traditionalaged college students experience (Chickering, 1969).

Chickering and Reisser (1993) later revised and reordered the original seven changes into the seven vectors of the identity development theory. The seven vectors in the theory include: (a) developing competence, (b) managing emotions, (c) moving through autonomy toward interdependence, (d) developing mature interpersonal relationships, (e) establishing identity, (f) developing purpose, and (g) developing integrity (Chickering \& Reisser, 1993).

The first developmental vector, developing competence, includes intellectual, physical and manual, and interpersonal competence. The second developmental vector is managing emotions. The third vector includes moving though autonomy toward interdependence and includes both emotional and instrumental independence to think critically and act on ideas (Chickering \& Reisser, 1993). Chickering and Reisser's (1993) fourth vector, developing mature interpersonal relationships, involves tolerating and appreciating differences among individuals and capacity for intimacy. The fifth vector, establishing identity, encompasses discovering the types of experiences at specific levels and frequencies that resonate in a satisfying, safe, or selfdestructive fashion (Chickering, 2007). The sixth vector involves developing purpose and includes formulating plans for action having a set of priorities (Chickering, 2007). The seventh and final vector, developing integrity, involves humanizing values, personalizing values, and 
finally, developing congruency between personalized values and behaviors (Chickering \& Reisser, 1993).

According to Chickering (1969), students' movement through the seven vectors, unlike stages, is not unilateral or mutually exclusive. Students can move along the vectors at different rates, while at the same time interact with the other vectors. In fact, after movement in one vector, there can be movement in a previous vector, still indicating development of the student (Chickering \& Reisser, 1993). Moreover, "each step from 'lower' to 'higher' brings more awareness, skill, confidence, complexity, stability, and integration but does not rule out an accidental or intentional return to ground already traversed" (Chickering \& Reisser, 1993, p. 34).

\section{Our Journey to Understand}

This qualitative study was accomplished through the instrumental case study approach (Stake, 1995) in which we employed document analysis of an archived course assignment to analyze the students' perceptions of their personal leadership development. The case was bounded by the undergraduate personal leadership development course. Stake (1995) explained, "[g]athering data by studying documents follows the same line of thinking as observing or interviewing" (p. 68). The archived class assignment served as the data collection tool for the study. The archived data were collected through a writing exercise generated by students enrolled in two sections of an undergraduate personal leadership development course and was taught by two different instructors in the College of Agricultural Sciences and Natural Resources at Oklahoma State University. Early in the semester, students were asked to introduce themselves and indicate any prior leadership experiences. Most students indicated some leadership experience and training in the context of youth personal development organizations such as 4-H and the National FFA Organization. However, it is assumed, as this is a foundational leadership course, that the students never had a formal personal development course at the collegiate level.

Throughout the semester, students participated in numerous discussions, experiential activities, and written reflections to help them articulate their values, vision, profile, and organizational and personal realities. In-class and out-of-class exercises were employed to guide students in the self-exploration process. As supported by previous research, the classroom environment was open and creative, allowing for small group interaction and discussion, as opposed to using a traditional lecture style (Williams \& McClure, 2010; Wimmer et al., 2012). Both in-class and out-of-class activities allowed students to self-explore authentic leadership concepts (Pennington, 2006).

The students were prompted to draw their DLF (King et al., 2011) during the second class meeting (August) of the 16-week course in the fall semester 2013. At the conclusion of the semester (December), students were provided the following written instructions in a class handout and asked to respond with at least three complete sentences for each question:

Create a new Discovering Leadership Framework using the knowledge you obtained throughout the semester. You are to compare and contrast your two drawings and answer 
the following questions: 1) How has your Discovering Leadership Framework changed?; and 2) Why do you think the two images differ? If there are no notable differences, why do you think the two images remain the same? (Weeks, Brown, \& Scott, 2013)

For the purpose of this study, document analysis (Stake, 1995) was utilized to determine how students' DLF changed during a personal leadership development course. Documents are used as a symbolic representation that can be employed for description and analysis (Altheide, Coyle, DeVriese, \& Schneider, 2010). The documents can be used to explain and track discourse and use terminology, interpretations, and themes over time (Altheide et al., 2010). Students were allowed roughly 30 minutes in both class meetings to complete the assignments. The first assignment, to draw their perceived DLF, was given to students during the second class meeting. Therefore, the ideas and words used in the frameworks were solely those of the students, as no prior instruction or self-exploration had taken place at that time. Upon the conclusion of the semester, the students were given the final assignment of creating a new DLF and comparing the first DLF to the final DLF and responding in writing to the two questions noted above. After the course concluded we analyzed the students' work to determine the change in their DLF.

We analyzed 92 total questions regarding the students' changes in their DLF and 92 personalized DLF drawings, totaling 46 complete data sets (Creswell, 2013) collected from 20 male and 26 female traditional-aged college students. Four incomplete data sets consisted of less than two drawings or unanswered questions. The incomplete data sets were attributed to course attrition, course addition, and absenteeism and were eliminated from analysis.

To achieve an audit trail, data sets were organized according to the instructor of record. We randomly assigned numbers to the students' documents for citation purposes and individually analyzed the students' answers to the aforementioned questions regarding the DLF. Students were assigned numbers based upon the assigned instructor. For example, instructor A's students were assigned numbers 1 through 22 , and instructor B's students were assigned numbers 51 through 75. As these instructors were uniform with their curriculum and instruction, questions could arise regarding differences in language and metaphors used in class that could impact the students' DLF. Employing this number system allowed for us to better interpret the data presented in the DLF assignment if questions arose. Further, we coded the data individually. To achieve triangulation, we referenced the students' DLF drawings and compared them to their respective answers to the questions (Tracy, 2010). Hence, coding and triangulation were employed to collectively negotiate themes through a constructivist and interpretive approach (Creswell, 2013). The themes were carefully analyzed for vocabulary usage, personal development, and cognitive growth.

A good qualitative researcher is both trustworthy and credible (Lincoln \& Guba, 1985). Both credibility and ethical conduct were made top priority during the research process (Tracy, 2010). Quotations were used from the documents to enhance the interpretation of the case. We exercised memoing (Creswell, 2013) during the analysis of the archived class assignment. The memoing reflected thoughts, viewpoints, and past experiences grasped in coding and the reporting phases of the study. This enhanced our ability to present thick and rich descriptions and provide concrete details (Tracy, 2010) regarding the students' DLF. 
Researcher predispositions are existent in all forms of social science research (Guba \& Lincoln, 1989). Three of the four researchers were instructors for the personal leadership development course, while the fourth researcher was added to the team due to her interest in case study research. Additionally, we openly reflected upon our individual strengths to aid in mitigating biases. For example, one researcher had an extensive background in leadership education, while two other researchers had a broad background in agricultural education. Additionally, another researcher had a vast knowledge of extension education. The strengths from each researcher provided alternative viewpoints regarding the interpretation of the documents. The viewpoints were presented and negotiated to help combat biases. However, it is possible that unintentional biases exist because of the expectations of the instructors rather than the students' authentic perceptions.

\section{Assertions, Discussion, and Conclusions}

Emphasis on interpretation of documents, interviews, and observations is the most distinct characteristic of qualitative inquiry (Stake, 1995). Based upon our understanding and previous knowledge and experiences, we compiled the issues, examined the issues, and negotiated themes and assertions to better report the data from the archived class assignment (Stake, 1995). As a result, four themes surfaced: (a) self-evolution, (b) cognitive gain, (c) perceived self-awareness, and (d) framework confusion.

\section{Self-Evolution}

Chickering and Reisser (1993) determined that students progress through seven vectors of identity development. As a result, students are enhancing their interpersonal competence, increasing their ability to manage emotions, becoming more independent, expanding their critical thinking skills, developing intrapersonal relationships, achieving self-discovery, and establishing an identity and values (Chickering \& Reisser, 1993). Consistent with the theory of identity development, students reported personal growth both in maturity and in openness to other viewpoints. "My [DLF assignments] differ because I have grown as a person and have learned to be more diverse and to look at life from all perspectives" [56:2]. Students consistently reported increased maturity between the time the first DLF was assigned and constructed to the final DLF assignment. Specifically, their values and attitudes toward their future matured: "After this class my values and attitude toward my career have grown" [55:1]. King et al. (2011) speculated that time is needed for individuals to venture through the DLF process. Therefore, most students reportedly progressed their "ideas, thoughts, and insights about [themselves] and [their] situation" (King et al., 2011, p. 149) as expected by the course objectives and instructors.

In addition, students consistently reported having more life and career focus. "The [DLFs] have changed because they have been tailored to be more focused towards the future" [51:2]. Students' focus on the future might be attributed to exposure to classroom situations that require reasoning and critical thinking. Ricketts (2005) suggested that students who are exposed to leadership experiences have additional opportunities to develop self-awareness and critical thinking skills. The promotion of critical thinking and reasoning ability is further observed in the theory of identity development as students move through the vector of developing competence (Chickering \& Reisser, 1993). 
Students also reported an awareness of lack of maturity, organization, and grounded reality. "My framework has changed because I wasn't as organized or mature in the beginning" [53:2]. Students evolve and often achieve self-authorship in college, meaning that students construct an internal sense of identity, intercultural maturity, and interpersonal loyalties (Kegan, 1994; King \& Magolda, 2005). Students who are self-aware internalize their values, permitting decision-making (Goleman, 1998). This was revealed from the students in the personal leadership development course through the evolved DLF. The time passed between the initial assignment and the last assignment promoted maturation of personal development concepts discussed during the course. Therefore, the students' maturation might have stimulated an increase in emotional intelligence (Goleman, 1998).

King et al. (2011) conjectured that time and necessary interventions are required for students to evolve from drift to clarity. As a result of the course, students reported successfully attaining clarity. "In my past, I was more in drift. I realized when I completed my second [DLF], I pulled out of drift" [3:1-2]. Students felt like they were initially disconnected, dissatisfied, and uncomfortable with being in leadership positions, a finding supported by King et al.(2011). However, at the conclusion of the personal leadership development course, students recognized that they had moved from a state of drift to clarity by following a process that included personal reflection, instructor guided exercises, and class discussions. "I had more clarity in my recent one" [3:1]. Questions posed to the students at the beginning of the semester promoted a plan of action for leaders to move from drift to clarity. While not part of the data set, these questions for thought included (King et al., 2011, p. 9):

1. How much of your life today involves being a leader?

2. Are you currently in a leadership role? How did you get there?

3. Do you see yourself as a leader? Are you a leader all of the time?

4. How comfortable are you with your identity as a leader?

5. Did you choose to become a leader, or did it somehow choose you?

Students' reflections on their current leadership status and efficacy could have helped foster and guide overall personal development. Students in the personal leadership development course could have moved from drift to clarity without the use of the reflective process and action plan.

Students enrolled in the personal leadership development course have the opportunity to move through the vectors of identity development (Chickering \& Reisser, 1993) as they identify their leadership vision and values, hence developing authenticity: "The more recent [DLF] evolved and is more fitting to the guideline of authenticity and is better linked to my passion" [15:2]. At the beginning of the class, students were unclear about leadership vision: "In the beginning I didn't grasp the concept of what a leadership vision even was" [62:2]. However, through open class discussions, small group work, and personal reflection assignments, students explored their personal values and leadership vision: "I know I will be able to realize more when my life doesn't have balance with my personal vision and my leadership vision and [I will] try to create congruency" [18:1]. Although authentic leadership is a lifelong journey, students took the first step in this journey as they committed to their core values and examined congruence with their actions: "[I] know who I am, and know my values" [71:2]. 


\section{Cognitive Gain}

Students reported an increase in their cognitive gain as a result of the personal leadership development course, remaining consistent with previous literature (Bennis, 1994; Brungardt \& Crawford, 1996; Williams et al., 2005; Wimmer et al., 2012). The type of information gained by the students as a result of the course according to the DLF included increasing leadership language, understanding their personal purpose, and expanding their scope: "My frameworks have changed because I have learned more throughout the semester what each [component] means, and I have discovered what I want from myself as a leader" [69:2]. Students who are capable of growing and moving toward clarity and have a better understanding of their views are more likely to become stable productive leaders (King et al., 2011): "I know now that there are things I can do to be a more effective leader" [54:1]. Integrating course concepts alongside the students' personal experiences helped them to clarify their visions: "Throughout the semester I have gained more knowledge and have a better understanding of looking toward the future" [58:2]. As students participated in the course exercises helping them move from drift to clarity, they "learned the importance of leadership" [64:2].

In addition, students overwhelmingly reported increased awareness of terminology and a deeper understanding of the DLF: "The instructor implemented terminology from the textbook, therefore I learned [and understood] more terms from the books: "After learning all that we did this semester, I think that my framework will continue to evolve and change as time goes by" [7:2]. As a result of knowing proper leadership terminology, the students' DLFs changed: "The notable differences are that the newer version is more straightforward and in correct and more influential terms" [56:2]

Students understood the components necessary for their journey to leadership clarity, which closely aligns with the third vector of the identity development theory, interdependence (Chickering \& Reisser, 1993): “[I] learned more about leadership and how to apply it to my life. I hope that I will be able to apply this in my life" [2:1]. Furthermore, students were better at employing reasoning and critical thinking skills and understanding the intended outcome of the course. Completing the final DLF assignment, "I understood the meanings of the [DLF components] and could better apply my answers to myself and the roles I play in life" [75:1-2]. The leadership development course provided students with opportunities to further develop their identity (Chickering, 1969).

\section{Perceived Self-Awareness}

Several students in the personal leadership development course reported not experiencing any notable change between the two parts of the DLF assignment: "[My] framework hasn't really changed from the beginning of the semester to now" [13:1]. It is possible that these students' perceived self-awareness was too resistant to allow for growth and evolution of personal leadership development. Perhaps the students were not as engaged with the DLF process as their peers. The students' perceived level of self-awareness could have had an indirect effect regarding their personal leadership development. 
Other students questioned the outcome: "There really [was not] a big change between my two leadership frameworks, and I'm not sure if that's a good thing or a bad thing" [59:2]. Perhaps these students were stagnant in their personal development because they were not yet ready to try new development approaches (King et al., 2011). Additionally, the approaches used in the course may not have been conducive to all types of students.

Moreover, students with a high perceived self-awareness might have already advanced through the identity development theory vectors (Chickering \& Reisser, 1993) through previous informal leadership experiences. Since this course was a foundational leadership course, most students enrolled had not yet taken any formal leadership development or leadership theory courses. However, during the introductory portion of the course at the beginning of the semester, several students indicated some facet of previous leadership training.

Since the personal leadership development course is offered through the agricultural leadership department and many of the students are assumed to have previous exposure to 4-H or the National FFA Organization, previous leadership exposure is plausible. Perhaps these are the students who reported no significant changes between their DLF assignments: "It was the same. There were no notable differences" [63:1-2]. If so, are students capable of advancing through the seven vectors (Chickering \& Reisser, 1993) without formal guidance?

Students with prior informal leadership experiences could have moved through the identity development vectors (Chickering \& Reisser, 1993) more quickly than their peers. If these students are indeed the individuals that noted having some type of leadership training and advanced through the seven vectors of identity development (Chickering \& Reisser, 1993), what is the likelihood that they could repeat the cyclical process and further enhance their personal leadership development, or is the process only effective during the first implementation?

\section{Framework Confusion}

When examining the two parts of the DLF archived class assignment, several students employed the word goal repetitively: "Some differences may change due to more determination to achieve my life goals" [68:2]; "The end goal has stayed the same" [18:2]. We found this to be intriguing, as goals were never addressed within the personal leadership development course. Perhaps students were unclear on the difference between vision and goals: "I'm more focused on my goals" [12:1]. As goals were not part of the course curriculum, perhaps students assumed that vision and goals were synonymous. The instructors operationalized vision as the students' overall image of their future including personal direction and personal growth (Fritz, Brown, Lunde, \& Banset, 2005). Goals indicate the specific means to direct one's time and energy to achieve one's vision (Fritz et al., 2005). Possibly, these select students did not master the content the instructors provided. Students could have learned this term through previous informal leadership experiences and trainings.

Furthermore, several students reported not understanding the first DLF assignment, as no prior knowledge about the framework was taught: "I didn't know what to put" [5:1]. Banks (2008) denoted that images created by individuals without any knowledge is an acceptable method of data collection. In this case, the students' first DLF assignment was given as a pre-test 
of knowledge. We used the archived data to compare changes in the students' personal leadership development. The students reported a better understanding of the DLF in the second assignment: "I think the second one is more focused because by now at the end of the course I have a better understanding of my Leadership Framework" [52:2].

The DLF is relatively new to leadership curriculum, as little to no research was found implementing the framework (King et al., 2011) in a leadership course of any kind. Based upon our assertions, the framework can be used as curriculum in other leadership courses as a method of personal leadership development along the journey to authenticity. The open, creative learning environment coupled with the variety of activities and assignments elicited a change in the students' DLF. Ultimately, the framework could serve as a foundation for students as they journey toward authenticity.

\section{Recommendations}

Although generalized recommendations are not typical conventions of qualitative research (Creswell, 2013), we offer suggestions for leadership educators and recommendations for further inquiry where appropriate. To help students evolve from drift to clarity, a variety of teaching methods could be used to convey course content, which in turn would promote critical thinking and reasoning skills among the students, leading to an increase in student focus. To support cognitive gain, leadership practitioners may consider synthesizing course concepts with the students' leadership visions and values, helping them to think about their futures and develop plans to realize their leadership visions. Additionally, teaching proper leadership terminology could further enhance this process. Because many students do come to the course with previous leadership training experiences from other organizations, we suggest that course instructors be mindful and be prepared to address the students' perceived self-awareness. Further research is warranted to explore the interaction between knowledge obtained via high school youth development organizations and formal collegiate leadership courses. Leadership educators may also consider addressing all change styles of their students so that more of them could be able to grow in their leadership development. Even though goals are not a component of the DLF, instructors are encouraged to differentiate between leadership vision and goals early in the semester, hopefully alleviating framework confusion. Finally, this case study suggests that instructors should guide students throughout their journey, which ultimately culminates in an understanding of the DLF.

In conclusion, the students enrolled in the personal leadership development course evolved in their pursuit of authentic leadership while also experiencing cognitive gain allowing them to communicate with others in a common leadership language. Leadership educators are encouraged to recognize that if students already have a perceived self-awareness, their willingness to change will be limited. Lastly, students' lack of comprehension can be a barrier to developing authentic leaders. 


\section{References}

Altheide, S., Coyle, M., DeVriese, K., \& Schneider, C. (2010). Emergent qualitative document analysis. In S. N. Hesse-Biber \& P. Leavy (Eds.), Handbook of emergent methods. New York, NY: Guilford Press.

Andenoro, A. C., Allen, S. J., Haber-Curran, P., Jenkins, D. M., Sowcik, M., Dugan, J. P., \& Osteen, L. (2013). National leadership research education agenda 2013-2018: Providing strategic direction for the field of leadership education. Retrieved from Association of Leadership Educators website: http://www.leadershipeducators.org/ResearchAgenda

Avolio, B. J., \& Gardner, W. L. (2005). Authentic leadership development: Getting to the root of positive forms of leadership. The Leadership Quarterly, 16(3), 315-338.

doi:10.1016/j.leaqua.2005.03.001

Banks, M. (2008). Using visual data in qualitative research. Thousand Oaks, CA: Sage Publications.

Bennis, W. (1994). On becoming a leader. Reading, MA: Addsion-Wesley.

Brungardt, C., \& Crawford, C. B. (1996). A comprehensive approach to assessing leadership students and programs: Preliminary findings. The Journal of Leadership Studies, 3(1), 37-48. doi: 10.1177/107179199600300105

Campbell, J. D., Trapnell, P. D., Heine, S. J., Katz, E. M., Lavallee, L. F., \& Lehman, D. R. (1996). Self-concept clarity: Measurement, personality correlates, and cultural boundaries. Journal of Personality and Social Psychology, 70(1), 141-156. doi: 10.1037/0022-3514.70.1.141

Cherniss, C., \& Goleman, D. (1998). Bringing emotional intelligence to the workplace. Retrieved from The Consortium for Research on Emotional Intelligence in Organizations website: http://www.eiconsortium.org

Chickering, A. W. (1969). Education and identity. San Francisco, CA: Jossey-Bass.

Chickering, A. W. (2007). The seven vectors: An overview. Retrieved from http://faculty.winthrop.edu/fullerb/QEP/7\%20vectors\%20of\%20development.pdf

Chickering, A. W., \& Reisser, L. (1993). Education and identity (2nd ed.). San Francisco, CA: Jossey-Bass.

Creswell, J. W. (2013). Qualitative inquiry \& research design: Choosing among five approaches (3rd ed.). Los Angeles, CA: Sage Publications.

Fritz, S., Brown, F. W., Lunde, J. P., \& Banset, E. A. (2005). Interpersonal skills for leadership (2nd ed.). Upper Saddle River, NJ: Prentice Hall, Inc. 
Gardner, W. L., Avolio, B. J., Luthans, F., May, D. R., \& Walumbwa, F. (2005). "Can you see the real me?" A self-based model of authentic leader and follower development. The Leadership Quarterly, 16(3), 343-372. doi: 10.1016/j.leaqua.2005.03.003

Goleman, D. (1998). What makes a leader? Harvard Business Review, 76(6), 93-102. Retrieved from http://hbr.org/magazine

Guba, E. G., \& Lincoln, Y. S. (1989). Fourth generation evaluation. Newbury Park, CA: Sage Publications.

Halpern, D. F. (2000, March). Creating cooperative learning environments. APS Observer, 14$15,29-31$.

Kaiser Family Foundation. (2005). Generation M2: Media in the lives of 8-18year-olds. Retrieved from http://www.kff.org/entmedia/7251.cfm

Kegan, R. (1994). In over our heads: The mental demands of modern life. Cambridge, MA: Harvard University Press.

Kernis, M. H. (2003). Toward a conceptualization of optimal self-esteem. Psychological Inquiry, 14(1), 1-26. doi: 10.1207/S15327965PLI1401_01

King, S. N., Altman, D. G., \& Lee, R. J. (2011). Discovering the leader in you. San Francisco, CA: Jossey-Bass.

King, P. M., \& Magolda, M. B. (2005). A developmental model of intercultural maturity. Journal of College Student Development, 46(6), 571-592. doi: 10.1353/csd.2005.0060

Lincoln, Y. S., \& Guba, E. G. (1985). Naturalistic inquiry. Beverly Hills, CA: Sage Publications.

Lloyd-Walker, B., \& Walker, D. (2011). Authentic leadership for 21st century project delivery. International Journal of Project Management, 29(4), 383-395. doi:

10.1016/j.ijproman.2011.02.004

Mayer, J. D., \& Salovey, P. (1993). The intelligence of emotional intelligence. Intelligence, 17(4), 433-442. doi: 10.1016/0160-2896(93)90010-3

Pennington, P. (2006). Authentic leadership in the college classroom. Academic Exchange Quarterly, 10(2), 12-16. Retrieved from http://rapidintellect.com/AEQweb/edchoiceold.htm

Prochaska, J. O., Norcross, J. C., \& DiClemente, C. C. (1994). Changing for good: The revolutionary program that explains the six stages of change and teaches you how tofree yourself from bad habits. New York, NY: W. Morrow. 
Raines, C. (2002). Managing millennials. Retrieved from http://www.generationsatwork.com/articles/millenials.htm

Ricketts, J. C. (2005). The relationship between leadership development and critical thinking skills. Journal of Leadership Education, 4(2), 27-41. Retrieved from http://www.fhsu.edu/jole/issues/jole_4_2.pdf\#page=31

Rosenshine, B., \& Furst, M. (1973). Research on teacher performance criteria. In B. O. Smith (Ed.). Research in teacher education-A symposium. Englewood Cliffs, NJ: Prentice Hall, Inc.

Stake, R. E. (1995). The art of case study research. Thousand Oaks, CA: Sage Publications.

Tracy, S. J. (2010). Qualitative quality: Eight "big-tent" criteria for excellent qualitative research. Qualitative Inquiry, 16(10), 837-851. doi: 10.1177/1077800410383121

Ungerer, J. A., Waters, B., Barnett, B., \& Dolby, R. (1997). Defense style and adjustment in interpersonal relationships. Journal of Research in Personality, 31(3), 375-384. doi: 10.1006/jrpe.1997.2192

Vaillant, G. (1992). Ego mechanisms of defense: A guide for clinicians and researchers. Washington, D.C.: American Psychiatric Press.

Weeks, P. P., Brown, N. R., \& Scott, M. (2013). Syllabus for AGLE 2303 Personal Leadership Development in Agricultural Sciences and Natural Resources. (Available from Oklahoma State University Department of Agricultural Education, Communications, and Leadership)

Weisinger, H. (1998). Emotional intelligence at work. San Francisco, CA: Jossey-Bass.

Williams, J. R., \& McClure, M. (2010). The effects of teaching methods in leadership knowledge retention: An experimental design of lecture, experiential, and public pedagogy. Journal of Leadership Education, 9(2), 86-100. Retrieved from http://www.leadershipeducators.org/JOLE

Williams, J. R., Townsend, C. D., \& Linder, J. R. (2005). Teaching leadership: Do students remember and utilize the concepts we teach? Journal of Leadership Education, 4(1), 6274. Retrieved from http://www.leadershipeducators.org/JOLE

Wimmer, G., Meyers, C., Porter, H., \& Shaw, M. (2012). Learning vicariously: Students' reflections of the leadership lessons portrayed in The Office. Journal of Leadership Education, 11(2), 52-71. Retrieved from http://www.leadershipeducators.org/JOLE 


\section{Author Biographies}

Meagan Scott is a graduate teaching associate in Agricultural Leadership at Oklahoma State University. Previously, she worked as a 4-H youth agent, emphasizing youth leadership in her program. Her interests include leadership education in the classroom and working with the Cooperative Extension Service to assist 4-H youth develop leadership skills.

Ashley S. Whiddon is a doctoral candidate at Oklahoma State University and serves as an agricultural education teacher at Peach County High School in Fort Valley, Georgia. Her area of focus involves project-based learning and teacher education.

Dr. Nicholas R. Brown serves as an assistant principal at Jenks Middle School within the Jenks Public School District in the Tulsa, Oklahoma metropolitan area. He is interested in investigating effective leadership practices among urban school administrators.

Dr. Penny P. Weeks currently serves as a Professor at Oklahoma State University in Agricultural Leadership. Since her arrival at OSU in 2001, Dr. Weeks has led the effort to develop an undergraduate Agricultural Leadership major and a Leadership Education minor for students in the College of Agricultural Sciences and Natural Resources. Dr. Weeks has served as the President of the Association of Leadership Educators and Project Director for the Leadership Education Institute, a USDA funded project. Her interests include Agricultural Leadership, Food Security and Hunger, and Leadership Education. 